\title{
EFFECTIVENESS OF SOME PLANT DUSTS AND INSECTICIDES AGAINST LESSER GRAIN BORER-RHIZOPERTHA DOMINICA (F)(COLEOPTERA: BOSTRYCHIDAE)
}

\author{
EL-LAKWAH, F.A. ${ }^{1}$, A.A. DARWISH ${ }^{1}$, \\ R.A. MOHAMED ${ }^{2}$ AND MANAR Y. ALY ${ }^{2}$
}

1 Plant Protection Dept. Fac. of Agric. Moshtohor-Benha University.

2 Plant Protection Research Institute, ARC, Ministry of Agric., Egypt

(Manuscript received 28 November 2010 )

\begin{abstract}
The aim of this study was to investigate the efficacy of some plant dusts i.e. black pepper seeds dust (Piper nigrum L.); Cloves flowering buds (Syzegium aromaticum); Chili fruits dust (Capsicum frutescens); Cinnamon dust (Cinnamonum zeylanicum); Diatomaceous earth (DE) dust in comparison with katel-sous dust against Rhizopertha dominica (F.) at $30 \pm 1^{\circ} \mathrm{C}$ and $65 \pm 5 \% \mathrm{RH}$, also the efficacy of two organophosphorus insecticides namely malathion and piromiphos -methyl (Actellic) and one botanical insecticide (Neemazal T/S 1\% Azadirachtin) was evaluated. The results indicated that adult mortality was concentration and exposure period dependent. Adult mortality was increased with increasing the dust concentration and exposure period.

The results of the various dusts against Rhizopertha dominica adults indicated that DE was the most effective followed by black pepper dust, cloves flowering dust, katel-sous dust and chili dust which was the least effective one. On the other hand the highest tested cinnamon dust concentration $(6 \% \mathrm{w} / \mathrm{w})$ resulted a lower mortality (less than 40\%) even after two weeks from treatment.

Results of the toxicity index of the various tested insecticides against Rhizopertha dominica (F.), revealed that Actellic was the most effective followed by Malathion and Neemazal which was the least effective one.
\end{abstract}

\section{INTRODUCTION}

The lesser grain borer Rhizopertha dominica (F.), (Coleoptera: Bostrychidae) is a primary pest of cereal grains and other seeds; also feeds on dried potatoes, tapioca and herbs. Larvae and adults bore into grain eating out the entire starchy interior and the seed coat in places, leaving irregularly-shaped holes. Large quantities of floury dust are produced. Heavily infested wheat has a honey- like odour.

Neem products show a considerable potential in the control of stored product pests (Saxena et al., 1984). In this connection repellent effects are of importance. For instance, the treatment of jute sacks by using neem oil or AZ- rich products prevents the penetration of pasts for several months, for example of Sitophilus spp. and Tribolium spp. Neem oil shows a strong ovicidal effect in brucgids (Yadav, 1985), 
but its antifeedant and other efficacies may also be important in controlling these legume pests (Ketkar, 1987).

\section{Thus the aim of this work was to study:-}

1- Investigate the efficacy of some plant dusts namely:- Black pepper (piper nigrum) (L.), cloves flowering buds (syzygium aromaticum), chili dust (capsicum frutescens), cinnamon (cinnamonum zeylanicum), Diatomaceous earth and katel sous against Rhizopertha dominica (F.).

2- Investigate the efficacy of some insecticides namely:- Neemazal T/S $1 \%$ azadirachtin, Actellic EC 50\% (pirimiphos methyl) and malathion EC 57\% against Rhizopertha dominica (F.).

\section{MATERIALS AND METHODS}

\section{* Insects:}

Laboratory strain of the Rhizopertha dominica(F.) the lesser grain borer, (Bostrychidae, Coleoptera) was used during this work. Insects were collected from the stores during 2006 and maintained at the stored product pests' laboratory of the plant protection Dept. Faculty of Agric., Moshtohor Benha University.

\section{* Insect cultures}

Adults were reared in glass jars of approx. $250 \mathrm{ml}$. , each jar contained about $450 \mathrm{~g}$. of wheat kernels for $R$. dominica and covered with muslin cloth and fixed with rubber band. Insect cultures were kept under controlled conditions of $30 \pm 1^{\circ} \mathrm{C}$ and $65 \pm 5 \%$ R.H. at the rearing room of the laboratory. Wheat grains were treated well by freezing at $-18^{\circ} \mathrm{C}$ for 2 weeks before application to eliminate any possible infestation by any insect species. The moisture content of the grains was about $14 \%$.

Adults samples were exposed to the various treatments for varying length of time. After the desired exposure period mortality assessment was performed. Mortality percentages were corrected by Abbott's formula (1925).

\section{Grain protectants tested :-}

Katel-sous (KS): A dust powder formulation (contains $84 \%$ calcium triphosphate plus $16 \%$ sulpher, produced by Kafr El-Zayat Company for Pesticides, Egypt), was mixed with wheat grains and tested at $6,4,2,1$ and $0.5 \%(\mathrm{w} / \mathrm{w})$ concentrations.

Diatomaceous earth (DE): Algae Diatomes in the form of rigid, rocky mountains and it was grounded into fine powder. 
A dust powder formulation (contains $97 \%$ Silicon dioxide produced by Fabrique par, Hedley Pacific Ventures Ltd., Vancouver, B.C., Canada) was mixed with wheat grains and tested at 6, 4, 2, 1 and $0.5 \%(\mathrm{w} / \mathrm{w})$ concentrations.

\section{ACTELLIC EC 50\% (pirimiphos-methyl) (Organophosphorous compounds):}

Actellic EC $50 \%$ produced by ICI plant protection, LTD, England. Wheat grains were treated with actellic at 10, 7.5, 5, 2.5 and $1.25 \mathrm{mg} / \mathrm{l}$. all treatments were replicated three times. Mortality of adult insects was recorded after 1, 2, 3, 5, 7, 10 and 14 days.

\section{MALATHION EC 57\%: (Organophosphorous compound):}

Malathion EC $57 \%$ produced by American Cynamid, U.S.A. Wheat grains were treated at $30,20,15,10,7.5,5$ and $2.5 \mathrm{mg} / \mathrm{l}$. Mortality of adult insects was recorded after $1,2,3,5,7,10$ and 14days. Then the alive adult insects were removed after 14 days post- treatment and the grain was mentained at $30 \pm 1^{\circ} \mathrm{C}$, $65 \pm 5 \% \mathrm{RH}$ to obtain the $\mathrm{F} 1$ progeny after $30,45,60$ and 75 days from treatment. Adult mortality was corrected using Abbot's formula and inhibition rate of F1 progeny was recorded as mentioned above.

\section{NEEMAZAL- T/S 1\% Azadirachtin (botanical pesticide)}

Neemazal ( $\mathrm{T}$ ) $1 \%$, the botanical insecticide Neemazal-T, a liquid formulation contains 5\% Azadirachtin, which is an extract of the neem tree seeds (Azadirachta indica A.Juss), was obtained from Trifolio- GMBH Company, Germany.

Neemazal is a slow acting naturally based anti-feeding insecticide. Wheat grains were treated at 400,350, 300, 250, 200, 100 and $50 \mathrm{mg} / \mathrm{l}$. Mortality of adult insects was recorded after $1,2,3,5,7,10$ and 14 days. Then the alive adult insects were removed after 14 days post- treatment and the grain was maintained at $30 \pm 1^{\circ} \mathrm{C}, 65 \pm 5 \% \mathrm{RH}$ to obtain the $\mathrm{F} 1$ progeny after $30,45,60$ and 75 days from treatment. Adult mortality was corrected using Abbot's formula and inhibition rate of $\mathrm{F} 1$ progeny was recorded as mentioned above

\section{* Bioassay tests:-}

To assess the insecticidal potential of the used dusts and insecticides test arenas consisted of glass jars $(50 \mathrm{ml})$ were used. Each jar contained uninfested 30 gm of wheat kernels, which were thoroughly mixed by hand shaking with the weighed amount of the tested dust for the insecticides to give the required concentration. Batches of 30 unsexed adults ( 1 to 2 week-old) were introduced to the jars, with each species being tested separately. The jars were then covered with pieces of muslin, secured with rubber bands and kept under the aforementioned rearing conditions at the laboratory. All treatments were replicated three times. The contents of the jars were sifted through a $2 \mathrm{~mm}$ opening sieve to separate insects from the grains. The 
numbers of live and dead adults were counted and mortality percentages were accordingly determined at $1,2,3,5,7,10$ and 14 days post-treatment, and the F1 progeny was estimated after $30,45,60$ and 75 days post-treatment.

\section{* Plant dusts :-}

Black pepper dust:- (Piper nigrum)(L.) the dust was mixed with wheat grains and tested at $6,4,2,1$ and $0.5 \%(\mathrm{w} / \mathrm{w})$ concentrations. The fruit contains volatile oil, piperine and a resin ${ }^{1}$.

Chili dust:-( Capsicum frutescens) the dust was mixed with wheat grains and tested at $6,4,2,1$ and $0.5 \%(\mathrm{w} / \mathrm{w})$ concentrations. The fruit contains capsaicin. (E)-N-(4-hydroxy-3-methoxybenzyl)-8 methylnon- 6- enamide.

Cloves flowering buds dust:- (Syzygium aromaticum) the dust was mixed with wheat grains and tested at 6, 4, 2, 1 and $0.5 \%$ (w/w) concentrations. Cloves flowering buds dust (Syzygium aromaticum), which contain casuarictin and eugeniin (Tellimagrandin II) Okuda (1983).

Cinnamon dust:- (Cinnamonum zeylanicum) the dust was mixed with wheat grains and tested at $6,4,2,1$ and $0.5 \%(\mathrm{w} / \mathrm{w})$ concentrations. Dusts were tested after $1,2,3,5,7,10$ and 14 days. Then the alive adult insects were removed after 14 days post- treatment and the grain was maintained at $30 \pm 1{ }^{\circ} \mathrm{C}, 65 \pm 5 \% \mathrm{RH}$ to obtain the $\mathrm{F} 1$ progeny after 30, 45, 60 and 75 days from treatment. Adult mortality was corrected using Abbot's formula and inhibition rate of F1 progeny was recorded as mentioned above. Cinnamon dust (Cinnamonum zeylanicum), contain carpacin (Isosafrole methyl ether) Mohondas, (1969)

Tested seeds were bought from the local market and ground into fine powder in an electric mill. The powder was mixed with the insect feeding media to give the proper concentration.

\section{* Statistical Analysis:-}

A probit computer program was used for determining the dosage mortality response (Finney, 1971) for the dusts and insecticides, and also the lethal times for the gases.

\section{RESULTS AND DISCUSSION}

\section{Effect of some plant dusts against lesser grain borer (Rhizopertha dominica) (F.) at $30 \pm 1{ }^{\circ} \mathrm{C}$ and $65 \pm 5 \%$ R.H:-}

The results of the effect of Black pepper dust (Piper nigrum (L.)) on adult mortality and reduction in F1- progeny of Rhizopertha dominica(F.) at $30 \pm 1^{\circ} \mathrm{C}$ and 
$65 \pm 5 \%$ R.H. are presented in Table 1 . The results indicated clearly that mortality was concentration and exposure period dependent -The higher the concentration and the exposure period, the higher the mortality was. At $6 \%$ concentration mortality was $65.5 \%$ after 1 day exposure and increased to $99.9 \%$ at 14 days post treatment. At $4 \%$ concentration mortality was $56.6 \%$ at 1 day exposure and increased to 98 at 14 days post treatment. At $2 \%$ concentration mortality was $4.4 \%$ at 1 day exposure and increased to $90 \%$ at 14 days post treatment, At $1 \%$ concentration mortality was $2.2 \%$ at 1day exposure and increased to $60 \%$ at 14 days post treatment. At $0.5 \%$ concentration, mortality was $0 \%$ at 1 day exposure and increased to $40 \%$ at 14 days post treatment. Reduction in $F_{1}$ progeny was between $33.11-82.2 \%$ for the various tested concentrations of black pepper dust.

The lethal concentrations of black pepper dust against the adults of Rhizopertha dominica are given in table 2. The results showed that the lethal concentrations are exposure period dependent. The higher the exposure period was the lower the values. At 3 days post treatment the $L C_{50}$ value was $2.2 \%(w / w)$, the corresponding value at 14 days was significantly decreased and amounted $0.7 \%$ $(w / w)$.

The $\mathrm{LC}_{90}$ values was $7.1 \%(\mathrm{w} / \mathrm{w})$ at 3 days and declined to $2 \%(\mathrm{w} / \mathrm{w})$ at 14 days post treatment. The $\mathrm{LC}_{95}$ values was $10 \%(\mathrm{w} / \mathrm{w})$ at 3 days and decreased to 2.5 $\%(w / w)$ after 14 days from treatment.

Table 1. Effect of Black pepper dust (Piper nigrum (L.))on adult mortality and reduction in F1-progeny of Rhizopertha dominica (F) at $30 \pm 1{ }^{\circ} \mathrm{C}$ and $65 \pm 5 \%$ R.H.

\begin{tabular}{|c|c|c|c|c|c|c|c|c|c|}
\hline \multirow{2}{*}{$\begin{array}{l}\text { Conc. } \\
\% \text { w/w }\end{array}$} & \multicolumn{7}{|c|}{$\%$ Adult mortality after indicated period (days) } & \multirow{2}{*}{$\begin{array}{c}\text { Average No. of } \\
\text { emerged } \\
\text { adults after } 75 \text { days }\end{array}$} & \multirow{2}{*}{$\begin{array}{c}\% \text { Reduction in } \\
\text { F1-progeny }\end{array}$} \\
\hline & 1 & 2 & 3 & 5 & 7 & 10 & 14 & & \\
\hline 6 & 65.5 & 79.9 & 88.8 & 96.6 & 97.3 & 98.7 & 99.9 & 20.3 & 82.2 \\
\hline 4 & 56.6 & 65.5 & 84.4 & 92.2 & 96.6 & 97.7 & 98 & 26.3 & 77.1 \\
\hline 2 & 4.4 & 16.63 & 25.5 & 43.3 & 49.9 & 88.4 & 90 & 41.6 & 63.7 \\
\hline 1 & 2.2 & 6.63 & 13.3 & 23.3 & 28.8 & 50.9 & 60 & 49 & 57.2 \\
\hline 0.5 & 0 & 4.4 & 12.2 & 17.7 & 22.2 & 36.4 & 40 & 76.6 & 33.11 \\
\hline Control & 0 & 0 & 0 & 0 & 0 & 2.2 & 3.3 & 114.6 & 0 \\
\hline
\end{tabular}


Table 2. Lethal concentration of Black pepper dust against the adults of Rhizopertha dominica (F.) at various exposure Periods.

\begin{tabular}{|c|c|c|c|c|c|}
\hline \multirow{2}{*}{$\begin{array}{c}\text { Exposure } \\
\text { Period(Days) }\end{array}$} & \multicolumn{3}{|c|}{$\begin{array}{l}\text { lethal concentrations (\%w/w) } \\
\text { and their } 95 \% \text { confidence limits }\end{array}$} & \multirow[t]{2}{*}{ Slop \pm SD } & \multirow[t]{2}{*}{$\mathrm{R}$} \\
\hline & LC50 & LC90 & LC95 & & \\
\hline 3 days & $\begin{array}{c}2.2 \\
(2-3) \\
\end{array}$ & $\begin{array}{c}7.1 \\
(5-10.3) \\
\end{array}$ & $\begin{array}{c}10 \\
(6.4-15.4)\end{array}$ & $2.5 \pm 0.72$ & 0.9319 \\
\hline 5 days & $\begin{array}{c}1.5 \\
(1.2-2)\end{array}$ & $\begin{array}{c}4.4 \\
(3.2-6)\end{array}$ & $\begin{array}{c}6 \\
(4.1-9)\end{array}$ & $3 \pm 1.56$ & 0.9549 \\
\hline 7 days & $\begin{array}{c}1.3 \\
(1.1-2) \\
\end{array}$ & $\begin{array}{c}4 \\
(3-5) \\
\end{array}$ & $\begin{array}{c}5 \\
(3.4-7) \\
\end{array}$ & $3 \pm 0.70$ & 0.9467 \\
\hline 14 days & $\begin{array}{c}0.7 \\
(0.6-0.9)\end{array}$ & $\begin{array}{c}2 \\
(1.5-2.4)\end{array}$ & $\begin{array}{c}2.5 \\
(2-3.4)\end{array}$ & $3.03 \pm 0.23$ & 0.9849 \\
\hline
\end{tabular}

$\mathrm{R}=$ Correlation Coefficient of regression line.

$\mathrm{SD}=$ Standard deviation of the mortality regression line.

The results of the effect of cloves flowering buds dust (Syzygium aromaticum) on adult mortality and reduction in F1- progeny of Rhizopertha dominica(F.) at $30 \pm$ $1^{\circ} \mathrm{C}$ and $65 \pm 5 \% \mathrm{RH}$ are tabulated in table 3 . The results indicated clearly that mortality was concentration and exposure period dependent. At the highest tested concentration $6 \% \mathrm{w} / \mathrm{w}$, mortality values were $45.5 ; 54.4 ; 59.3 ; 75.5 ; 84.4 ; 88.88$ and $91.1 \%$ after $1,2,3,5,7,10$ and 14 days from treatment, respectively. At $4 \%$ concentrations, mortality values were 38.86, 49.95, 59.9, 78.86, 81.06, 84.4, 84.4\% after $1,2,3,5,7,10$ and 14 days from treatment, respectively. At $2 \%$ concentration, mortality values were 22.2, 29.96, 41.06, 48.8, 53.3, 57.77, 60 after 1, 2, 3, 5, 7, 10 and 14 days from treatment, respectively. At $1 \%$ concentration, mortality values were $9.96,15.5,18.8,22.16,24.2,26.6,28.75 \%$ after $1,2,3,5,7,10$ and 14 days from treatment. At $0.5 \%$ concentration, mortality values were $3.3,6.6,8.86,12.2,15.5$, $15.5,16.6 \%$ after $1,2,3,5,7,10$ and 14 days from treatment. Reduction in $\mathrm{F} 1$ progeny was between $14.4-100 \%$ for the various tested concentration of cloves flowering buds.

The lethal concentrations of cloves flowering buds dust against the adults of Rhizopertha dominica (F.) are tabulated in table 4. The results showed that the lethal concentrations are exposure period dependent. The higher the exposure period was the lower the values. At 7days post treatment the $\mathrm{LC}_{50}$ value was $2 \%(\mathrm{w} / \mathrm{w})$, the corresponding value at 14 days was significantly decreased and amounted $1.5 \%$ $(\mathrm{w} / \mathrm{w})$. The $\mathrm{LC}_{90}$ value was $7.5 \%(\mathrm{w} / \mathrm{w})$ at 7 days and declined to $5.6 \%(\mathrm{w} / \mathrm{w})$ at 14 days post treatment. The $\mathrm{LC}_{95}$ value was $11.3 \%(\mathrm{w} / \mathrm{w})$ at 7 days post treatment and decreased to $8.2 \%(\mathrm{w} / \mathrm{w})$ after 14 days post treatment. 
Table 3. Effect of cloves flowering buds dust (Syzygium aromaticum) on adult mortality and reduction in F1-progeny of Rhizopertha dominica (F.) at $30 \pm 1^{\circ} \mathrm{C}$ and $65 \pm 5 \%$ R.H.

\begin{tabular}{|c|c|c|c|c|c|c|c|c|c|}
\hline \multirow{2}{*}{$\begin{array}{l}\text { Conc. } \\
\% \mathrm{w} / \mathrm{w}\end{array}$} & \multicolumn{7}{|c|}{$\%$ Adult mortality after indicated period (days) } & \multirow{2}{*}{$\begin{array}{c}\text { Average No. of } \\
\text { emerged adults } \\
\text { after } 75 \text { days }\end{array}$} & \multirow{2}{*}{$\begin{array}{c}\text { \% Reduction in F1- } \\
\text { progeny }\end{array}$} \\
\hline & 1 & 2 & 3 & 5 & 7 & 10 & 14 & & \\
\hline 6 & 45.5 & 54.4 & 59.3 & 75.5 & 84.4 & 88.88 & 91.10 & 0 & 100 \\
\hline 4 & 38.86 & 49.95 & 59.9 & 78.86 & 81.06 & 84.4 & 84.4 & 0.066 & 99.9 \\
\hline 2 & 22.2 & 29.96 & 41.06 & 48.8 & 53.3 & 57.77 & 60 & 244.66 & 63.61 \\
\hline 1 & 9.96 & 15.5 & 18.8 & 22.16 & 24.2 & 26.6 & 28.75 & 492.66 & 26.72 \\
\hline 0.5 & 3.3 & 6.6 & 8.86 & 12.2 & 15.5 & 15.5 & 16.6 & 575 & 14.4 \\
\hline Control & 0 & 0 & 0 & 0 & 2.2 & 3.3 & 3.3 & 672.33 & 0 \\
\hline
\end{tabular}

Table 4. Lethal concentrations of cloves flowering buds dust against the adults of Rhizopertha dominica (F.) at various exposure Periods.

\begin{tabular}{|c|c|c|c|c|c|}
\hline \multirow{2}{*}{$\begin{array}{l}\text { Exposure } \\
\text { Period(Days) }\end{array}$} & \multicolumn{3}{|c|}{$\begin{array}{l}\text { lethal concentrations ( } \% \mathrm{w} / \mathrm{w}) \text { and their } 95 \% \\
\text { confidence limits }\end{array}$} & \multirow{2}{*}{ Slope \pm SD } & \multirow{2}{*}{$\mathrm{R}$} \\
\hline & $\mathrm{LC}_{50}$ & $\mathrm{LC}_{90}$ & $\mathrm{LC}_{95}$ & & \\
\hline 7 days & $\begin{array}{c}2 \\
(1.4-2.2)\end{array}$ & $\begin{array}{c}7.5 \\
(5-12) \\
\end{array}$ & $\begin{array}{c}11.3 \\
(7-19.12) \\
\end{array}$ & $2.05 \pm 0.76$ & 0.9884 \\
\hline 14 days & $\begin{array}{c}1.5 \\
(1.2-2)\end{array}$ & $\begin{array}{c}5.6 \\
(4-8.10)\end{array}$ & $\begin{array}{c}8.2 \\
(5.2-13)\end{array}$ & $2.2 \pm 0.041$ & 0.9947 \\
\hline
\end{tabular}

$\mathrm{R}=$ Correlation Coefficient of regression line.

$\mathrm{SD}=$ Standard deviation of the mortality regression line.

The results of the effect of chili dust (capsicum frutescens) on adult mortality and reduction in F1-progeny of Rhizopertha dominica(F.) at $30 \pm 1^{\circ} \mathrm{C}$ and $65 \pm 5 \%$ $\mathrm{RH}$ are shown in table 5 . The results indicated clearly that mortality was concentration and exposure period dependent. The higher the concentration and the exposure period, the higher the mortality was. At $6 \%$ concentration mortality value was $5.5 \%$ after one day post treatment and increased to $99 \%$ at 14 days exposure. At $4 \%$ concentration mortality value was $2.2 \%$ at 1 day exposure and increased to $92 \%$ at 14 days exposure. Concentration at $2 \%$ mortality was $3.3 \%$ at 1 day exposure and increased to $80.7 \%$ after 14 days post treatment. At $1 \%$ concentration mortality was $0 \%$ at one day exposure and increased to $78.7 \%$ at 14 days exposure. Concentration 
at $0.5 \%$ mortality was zero $\%$ at 1 day exposure and increased to $40.3 \%$ after 14 days post treatment. Reduction in F1 progeny was between $10.60-63.63 \%$ for the various tested concentration of chili dust.

The lethal concentrations of chili dust against the adults of Rhizopertha dominica(F.) are shown in table 6 . The results showed that the lethal concentrations are exposure period dependent the higher the exposure period was the owner the values. At 7days post treatment the $\mathrm{LC}_{50}$ value was $2 \%(\mathrm{w} / \mathrm{w})$ the corresponding value at 14 days was significantly decreased and amounted $0.59 \%(w / w)$. The $L_{90}$ value was $15.5 \%(\mathrm{w} / \mathrm{w})$ at 7 days and declined to $2.5 \%(\mathrm{w} / \mathrm{w})$ after 14 days post treatment. The $\mathrm{LC}_{95}$ value was $28.1 \%(\mathrm{w} / \mathrm{w})$ at 7 days and decreased to $4 \%(\mathrm{w} / \mathrm{w})$ after 14 days post treatment.

Table 5. Effect of chili dust (Capsicum frutescens) on adult mortality and reduction in F1-progeny of Rhizopertha dominica (F.) at $30 \pm 1^{\circ} \mathrm{C}$ and $65 \pm 5 \%$ R.H.

\begin{tabular}{|c|c|c|c|c|c|c|c|c|c|}
\hline \multirow{2}{*}{$\begin{array}{l}\text { Conc. } \% \\
\text { w/w }\end{array}$} & \multicolumn{7}{|c|}{$\%$ Adult mortality after indicated period (days) } & \multirow{2}{*}{$\begin{array}{c}\text { Average No. of } \\
\text { emerged adults after } \\
75 \text { days }\end{array}$} & \multirow{2}{*}{$\begin{array}{c}\% \text { Reduction in } \\
\text { F1-progeny }\end{array}$} \\
\hline & 1 & 2 & 3 & 5 & 7 & 10 & 14 & & \\
\hline 6 & 5.5 & 18.8 & 35.5 & 63.3 & 76.6 & 95.5 & 99 & 32 & 63.63 \\
\hline 4 & 2.2 & 11.1 & 14.4 & 55.5 & 69.9 & 91.06 & 92 & 37.33 & 57.57 \\
\hline 2 & 3.3 & 7.7 & 12.2 & 41.06 & 44.4 & 78.7 & 80.7 & 52.33 & 40.53 \\
\hline 1 & 0 & 4.4 & 8.86 & 25.5 & 38.8 & 56 & 78.7 & 72.33 & 17.80 \\
\hline 0.5 & 0 & 3.3 & 7.7 & 15.5 & 20.9 & 30 & 40.3 & 97.33 & 10.60 \\
\hline Control & 0 & 0 & 0 & 0 & 0 & 3.3 & 4.4 & 88 & 0 \\
\hline
\end{tabular}

Table 6. Lethal concentrations of chili dust against the adults of Rhizopertha dominica (F.) at various exposure periods.

\begin{tabular}{|c|c|c|c|c|c|}
\hline \multirow{2}{*}{$\begin{array}{c}\text { Exposure Period } \\
\text { (Days) }\end{array}$} & \multicolumn{3}{|c|}{ lethal concentrations (\%w/w) and their 95\% } & \multirow{2}{*}{ Slope \pm SD } & $\mathrm{R}$ \\
\cline { 2 - 4 } & $\mathrm{LC}_{50}$ & $\mathrm{LC}_{90}$ & $\mathrm{LC}_{95}$ & & \\
\hline \multirow{2}{*}{7 days } & 2 & 15.5 & 28.1 & \multirow{2}{*}{$1.4 \pm 0.45$} & 0.9851 \\
\hline \multirow{2}{*}{14 days } & $(1.4-3)$ & $(7-35)$ & $(10.3-77)$ & \\
\hline
\end{tabular}

$\mathrm{R}=$ Correlation Coefficient of regression line.

$\mathrm{SD}=$ Standard deviation of the mortality regression line 
The result of the effect of cinnamon dust (cinnamonum zeylanicum) on adult mortality and reduction in F1-progeny of Rhizopertha dominica(F.) at $30 \pm 1^{\circ} \mathrm{C}$ and $65 \pm 5 \% \mathrm{RH}$ are presented in table 7 . The results indicated clearly that mortality was increased by increasing the dust concentration and the period of exposure. At $6 \%$ concentration mortality was $12.2 \%$ at one day exposure and increased to $22.2 \%$ at 5 days exposure, and it was $32.3 \%$ at 10 days, which increased to $39.9 \%$ after 14 days post treatment. At $4 \%$ concentration mortality values were $8.86 \%$ at one day exposure and increased to $17.7 \%$ at 5 days exposure, and it was $24.43 \%$ at 10 days, which increased to $26.63 \%$ after 14 days post-treatment. At $2 \%$ concentration, mortality values were $1.1 \%$ at one day exposure and increased to $14.4 \%$ at 5 days exposure and it was $16.66 \%$ at 10 days, which increased to $24.4 \%$ after 14 days post-treatment. At $1 \%$ concentration, mortality values were zero $\%$ at 1 day exposure and increased to 6.6 at 5 days exposure and it was $10 \%$ at 10 days, which increased to 15.55 after 14 days post-treatment. At $0.5 \%$ concentration, mortality values were zero at 1 day exposure and increased to $7.7 \%$ at 5 days exposure and it was $8.8 \%$ at 10 days, which increased to $14.4 \%$ after 14 days post-treatment. Reduction in F1 progeny was between $8.6-68 \%$ for the various tested concentration of cinnamon dust.

The results indicated clearly that the efficacy of cinnamon dust against the adults of Rhizopertha dominica was moderately lowed (between $14.4-39.9 \%$ ).

Table 7. Effect of cinnamon dust (Cinnamonum Zeylanicum) on adult mortality and reduction in F1-progeny of Rhizopertha dominica(F.)

\begin{tabular}{|c|c|c|c|c|c|c|c|c|c|}
\hline \multirow{2}{*}{$\begin{array}{l}\text { Conc. } \\
\% \mathrm{w} / \mathrm{w}\end{array}$} & \multicolumn{7}{|c|}{$\%$ Adult mortality after indicated period (days) } & \multirow{2}{*}{$\begin{array}{l}\text { Average No. of } \\
\text { emerged adults } \\
\text { after } 75 \text { days }\end{array}$} & \multirow{2}{*}{$\begin{array}{c}\% \text { Reduction in } \\
\text { F1-progeny }\end{array}$} \\
\hline & 1 & 2 & 3 & 5 & 7 & 10 & 14 & & \\
\hline 6 & 12.2 & 13.3 & 16.6 & 22.2 & 27.7 & 32.3 & 39.9 & 147 & 68 \\
\hline 4 & 8.86 & 9.96 & 12.2 & 17.7 & 22.16 & 24.43 & 26.63 & 297 & 36 \\
\hline 2 & 1.1 & 8.8 & 13.3 & 14.4 & 15.55 & 16.66 & 24.43 & 311 & 33 \\
\hline 1 & 0 & 4.4 & 5.5 & 6.6 & 8.8 & 10 & 15.55 & 410.3 & 11.5 \\
\hline 0.5 & 0 & 4.4 & 5.5 & 7.7 & 8.7 & 8.8 & 14.4 & 424 & 8.6 \\
\hline Control & 0 & 0 & 0 & 0 & 2.2 & 2.2 & 3.3 & 464 & 0 \\
\hline
\end{tabular}


The results of the effect of diatomaceous earth dust on adult mortality and reduction in F1-progeny of Rhizopertha dominica(F.) at $30 \pm 1^{\circ} \mathrm{C}$ and $65 \pm 5 \%$ R.H. are presented in table 8 . The results indicated clearly that mortality was increased by increasing the dust concentration and the period of exposure .At $6 \%$ concentration mortality was $56.63 \%$ at 1 day exposure and increased to $100 \%$ after 14 days post treatment. At $4 \%$ concentration mortality was $42.2 \%$ at 1 day exposure and increased to $100 \%$ after 14 days post treatment. At $2 \%$ concentration mortality was $32.2 \%$ at 1 day exposure and increased to $100 \%$ after 14 days post treatment. At $0.5 \%$ concentration mortality was $8.8 \%$ at one day exposure and increased to $100 \%$ after 14 days post treatment.

Results indicated complete adult mortality after 14 days post-treatment for the various tested DE concentrations. The lethal concentrations of diatomaceous earth against the adults of Rhizopertha dominica(F.) are shown in table 9 :-

Reduction in F1 progeny was between $92-99 \%$ for the various tested concentration of diatomaceous earth dust.

The results showed that the lethal concentrations are exposure period dependent. The higher the exposure period was the lower the values. At 2 days post treatment the $\mathrm{LC}_{50}$ value was $1.3 \%(\mathrm{w} / \mathrm{w})$, the corresponding value at 3 days was significantly decreased and amounted $0.435 \%(\mathrm{w} / \mathrm{w})$. The $\mathrm{LC}_{90}$ value was $5.3 \%$ $(\mathrm{w} / \mathrm{w})$ at 2 days post treatment and decreased to $3.3 \%(\mathrm{w} / \mathrm{w})$ at 3 days post treatment. The $\mathrm{LC}_{95}$ value was $7.9 \%(\mathrm{w} / \mathrm{w})$ at 2 days post treatment and declined to $5.9 \%(\mathrm{w} / \mathrm{w})$ after 3 days post treatment.

Table 8. Effect of Diatomaceous earth dust on adult mortality and reduction in F1progeny of Rhizopertha dominica (F.) at $30 \pm 1^{\circ} \mathrm{C}$ and $65 \pm 5 \%$ R.H.

\begin{tabular}{|c|c|c|c|c|c|c|c|c|c|}
\hline \multirow{2}{*}{$\begin{array}{c}\text { Conc. } \\
\% \mathrm{w} / \mathrm{w}\end{array}$} & \multicolumn{6}{|c|}{$\%$ Adult mortality after indicated period (days) } & \multirow{2}{*}{$\begin{array}{c}\text { Average No. of } \\
\text { emerged adults } \\
\text { after 75 days }\end{array}$} & $\begin{array}{c}\text { \% Reduction in } \\
\text { F1-progeny }\end{array}$ \\
\hline 6 & 56.63 & 92.2 & 93.3 & 64.4 & 99 & 100 & 100 & 2 & 99 \\
\hline 4 & 42.2 & 76.6 & 91.06 & 95.5 & 95 & 98.8 & 100 & 0 & 100 \\
\hline 2 & 32.2 & 77.7 & 89.9 & 92.2 & 92 & 98.86 & 100 & 7.3 & 99 \\
\hline 1 & 13.3 & 41.06 & 73.3 & 77.7 & 88 & 98.8 & 100 & 9 & 99 \\
\hline 0.5 & 8.8 & 15.5 & 45.5 & 49.9 & 85 & 100 & 100 & 49.9 & 92 \\
\hline Control & 0 & 0 & 0 & 0 & 2.2 & 2.2 & 3.3 & 622.3 & 0 \\
\hline
\end{tabular}


Table 9. Lethal concentrations of Diatomaceous earth dust against the adults of Rhizopertha dominica (F.) at various exposure periods.

\begin{tabular}{|c|c|c|c|c|c|}
\hline \multirow{2}{*}{$\begin{array}{c}\text { Exposure } \\
\text { Period(Days) }\end{array}$} & \multicolumn{3}{|c|}{$\begin{array}{c}\text { lethal concentrations ( } \% \mathrm{w} / \mathrm{w}) \text { and their } 95 \% \\
\text { confidence limits }\end{array}$} & \multirow[t]{2}{*}{ Slope \pm SD } & \multirow[t]{2}{*}{$\mathrm{R}$} \\
\hline & $\mathrm{LC}_{50}$ & $\mathrm{LC}_{90}$ & $\mathrm{LC}_{95}$ & & \\
\hline 2 days & $\begin{array}{c}1.3 \\
(1.03-2)\end{array}$ & $\begin{array}{c}5.3 \\
(4-8)\end{array}$ & $\begin{array}{c}7.9 \\
(5-13)\end{array}$ & $2.1 \pm 0.24$ & 0.9655 \\
\hline 3 days & $\begin{array}{c}0.435 \\
(0.24-0.77)\end{array}$ & $\begin{array}{c}3.3 \\
(2.1-5.4)\end{array}$ & $\begin{array}{c}5.9 \\
(3.1-11.4)\end{array}$ & $1.5 \pm 0.77$ & 0.9499 \\
\hline 7 days & $\begin{array}{c}0.076 \\
(0.0081-0.61)\end{array}$ & $\begin{array}{c}1.13 \\
(0.63-2.04)\end{array}$ & $\begin{array}{c}2.5 \\
(1.2-5.3)\end{array}$ & $1.06 \pm 0.16$ & 0.9176 \\
\hline
\end{tabular}

$\mathrm{R}=$ Correlation Coefficient of regression line.

$\mathrm{SD}=$ Standard deviation of the mortality regression line.

The results of the effect of katel-sous dust on adult mortality and reduction in F1-progeny of Rhizopertha dominica(F.) at $30 \pm 1^{\circ} \mathrm{C}$ and $65 \pm 5 \%$ RH are given in table 10. The results indicated clearly that mortality was increased by increasing the dust concentration and the period of exposure at $6 \%$ concentration mortality was $8.86 \%$ at one day exposure and increased to $98.8 \%$ after 14 days post treatment. At $4 \%$ concentration mortality was $7.7 \%$ at 1 day exposure and increased to $80.8 \%$ after 14 days post treatment. At $2 \%$ concentration mortality was $4.4 \%$ at 1 day exposure and increased to $70.8 \%$ after 14 days post treatment. At $1 \%$ concentration mortality was $3.3 \%$ at 1 day exposure and increased to $56.6 \%$ after 14 days post treatment. At $0.5 \%$ concentration mortality was $1.1 \%$ at 1 day exposure and increased to $46.6 \%$ after 14 days post treatment. Reduction in F1 progeny was between $1.38-92 \%$ for the various tested concentration of Katel sous dust.

The results showed clearly that at the recommended rate of katel-sous (1\% w/w), the obtained mortality value of Rhizopertha dominca adults after 14 days posttreatment was only $56.6 \%$, whereas the lethal concentration of katel-sous needed for 95\% kill was 5.7\% w/w (Table 11). This result indicated that Rhizopertha dominca adults were less susceptible to katel-sous.

The results showed also that the lethal concentrations are exposure period dependent. The higher the exposure period was the lower the values. At 7 days post treatment the $\mathrm{LC}_{50}$ value was $1.21 \%(\mathrm{w} / \mathrm{w})$, the corresponding value at 14 days was significantly decreased and amounted $0.75 \%(\mathrm{w} / \mathrm{w})$. The $\mathrm{LC}_{95}$ value was $14.03 \%$ $(\mathrm{w} / \mathrm{w})$ at 7 days post treatment and declined to $5.7 \%(\mathrm{w} / \mathrm{w})$ after 14 days post treatment. 
Table 10. Effect of Katel-sous dust on adult mortality and reduction in F1-progeny of Rhizopertha dominica (F.) at $30 \pm 1^{\circ} \mathrm{C}$ and $65 \pm 5 \%$ R.H.

\begin{tabular}{|c|c|c|c|c|c|c|c|c|c|}
\hline \multirow[t]{2}{*}{ Conc. $\% \mathrm{w} / \mathrm{w}$} & \multicolumn{7}{|c|}{$\begin{array}{c}\% \text { Adult mortality after indicated } \\
\text { period (days) }\end{array}$} & \multirow{2}{*}{$\begin{array}{l}\text { Average No. of } \\
\text { emerged adults } \\
\text { after } 75 \text { days }\end{array}$} & \multirow{2}{*}{$\begin{array}{c}\% \text { Reduction in } \\
\text { F1-progeny }\end{array}$} \\
\hline & 1 & 2 & 3 & 5 & 7 & 10 & 14 & & \\
\hline 6 & 8.86 & 18.83 & 54.4 & 88 & 90.2 & 92.2 & 98.8 & 45 & 92 \\
\hline 4 & 7.7 & 17.7 & 34.4 & 70.3 & 72.8 & 79.9 & 80.8 & 56.3 & 90 \\
\hline 2 & 4.4 & 9.9 & 21.06 & 55.53 & 60.6 & 68.8 & 70.8 & 165 & 72 \\
\hline 1 & 3.3 & 6.6 & 8.86 & 25.4 & 42.2 & 44.4 & 56.6 & 411 & 29 \\
\hline 0.5 & 1.1 & 4.4 & 4.4 & 19.9 & 31.3 & 36.6 & 46.6 & 571 & 1.38 \\
\hline Control & 0 & 0 & 0 & 0 & 1.1 & 2.2 & 3.3 & 579 & 0 \\
\hline
\end{tabular}

Table 11. Lethal concentrations of Katel-sous dust against the adults of Rhizopertha dominica (F.) at various exposure periods.

\begin{tabular}{|c|c|c|c|c|c|}
\hline \multirow[t]{2}{*}{ Exposure Period(Days) } & \multicolumn{3}{|c|}{$\begin{array}{l}\text { lethal concentrations ( } \% \mathrm{w} / \mathrm{w}) \text { and their } 95 \% \\
\text { confidence limits }\end{array}$} & \multirow[t]{2}{*}{ Slope \pm SD } & \multirow[t]{2}{*}{$\mathrm{R}$} \\
\hline & $\mathrm{LC}_{50}$ & $\mathrm{LC}_{90}$ & $\mathrm{LC}_{95}$ & & \\
\hline 7 days & $\begin{array}{c}1.21 \\
(0.9-1.6)\end{array}$ & $\begin{array}{c}8.2 \\
(4.5-15) \\
\end{array}$ & $\begin{array}{c}14.03 \\
(7-30.2) \\
\end{array}$ & $1.5 \pm 0.11$ & 0.9721 \\
\hline 14 days & $\begin{array}{c}0.75 \\
(0.5-1.02)\end{array}$ & $\begin{array}{c}3.6 \\
(2.4-5.4)\end{array}$ & $\begin{array}{c}5.7 \\
(3.4-10)\end{array}$ & $1.9 \pm 0.7$ & 0.8918 \\
\hline
\end{tabular}

$\mathrm{R}=$ Correlation Coefficient of regression line.

$\mathrm{SD}=$ Standard deviation of the mortality regression line.

Table (12) indicated that the toxicity index of the various investigated dusts against $R$. dominica -adults indicated that Deatomaceons Earth (DE) dust was the most effective material against the adults of $R$. dominica, followed by black pepper, cloves flowering buds, Katel-sous and chili dust was the least effective dust. On the other hand application of cinnamon dust at the highest tested concentration (6\%) resulted in lower mortality values (less than $40 \%$ ) even after 14 days from treatment. In this respect, El-lakwah, et al. (1992) studied pulverized black pepper seed in the laboratory for toxicity, reduction of $F_{1}$ progeny and repellency effect against adults of Sitophilus oryzae (L.), Rhizopertha dominica (F.) and Tribolium castaneum (erbst.). Data showed that black pepper powder was very toxic to $S$. oryzae and gave complete 
protection to stored wheat after 7 days from the treatment. The results indicated that black pepper powder could be used as a protectant for grain against certain stored product insects, also Nikpay, (2006) reported that, diatomaceous earths (DE) are among the most promising alternative to synthetic insecticides. In stored product protection, (DE) have proved effective as structural treatments to storage facilities. DE at $5 \mathrm{~g} / \mathrm{m}^{2}$ was effective against $R$.dominica and T.castaneum.

Also, the obtained results are in harmony with the findings obtained by other investigators (El-Lakwah, et al. 1992; El-Lakwah, 1997; El-Kashlan, 1999 and ElLakwah et al., 2001).

Table 12. Toxicity index of various tested dusts against the adults of Rhizopertha dominca (F.) at $30 \pm 1^{\circ} \mathrm{C}$ and $65 \pm 5 \%$ R.H.

\begin{tabular}{|c|c|c|c|c|c|c|}
\hline \multirow[t]{2}{*}{ Treatment } & \multicolumn{2}{|c|}{$\begin{array}{l}\text { Lethal concentration } \\
\text { at } 7 \text { day }(w / w \%)\end{array}$} & \multicolumn{2}{|c|}{ Toxicity index } & \multirow[t]{2}{*}{$S L O P E \pm S D$} & \multirow[t]{2}{*}{$\mathrm{R}$. } \\
\hline & $\mathrm{LC}_{50}$ & $\mathrm{LC}_{90}$ & $\mathrm{LC}_{50}$ & $\mathrm{LC}_{90}$ & & \\
\hline $\begin{array}{c}\text { Diatomaceous earth } \\
\text { dust }\end{array}$ & 0.076 & 1.13 & 100 & 100 & $1.06 \pm 0.16$ & 0.9176 \\
\hline Black pepper dust & 1.3 & 4 & 5.8 & 28.25 & $3 \pm 0.70$ & 0.9407 \\
\hline Cloves flowering dust & 2 & 7.5 & 3.8 & 15.06 & $2.06 \pm 0.76$ & 0.9884 \\
\hline Katel sous dust & 1.21 & 8.2 & 6.2 & 13.78 & $1.5 \pm 0.11$ & 0.9721 \\
\hline Chili dust & 2 & 15.5 & 3.8 & 7.29 & $1.4 \pm 0.45$ & 0.9533 \\
\hline Cinnamon dust & -- & -- & -- & -- & -- & -- \\
\hline
\end{tabular}

\section{I.8. Effect of botanical insecticide Neemazal-T/S 1\% Azdirachtin against Rhizopertha dominica (F.) at $30 \pm 1^{\circ} \mathrm{C}$ and $65 \% \pm 5 \%$ R.H.}

The result of the effect of Neemazal - T/S 1\% azadirachtin on adult mortality and reduction in F1-progeny of Rhizopertha dominica (F.) at $30 \pm 1^{\circ} \mathrm{C}$ and $65 \pm 5 \%$ R.H. are presented in table 13 . The results indicated clearly that mortality was increased by increasing the pesticide concentration and the period of exposure. At 400 ppm concentration, mortality values were 82.16, 90, 98.9, 99, 99.8, 99.9, $99.9 \%$ after $1,2,3,5,7,10$ and 14 days from treatment. At 350 ppm concentration, mortality values were 47.7, 67.7, 83.3, 94.4, 97.7, 99, 99.7\% after 1, 2, 3, 5, 7, 10 and 14 days from treatment. At $300 \mathrm{ppm}$ concentration, mortality values were 37.7 , 43.2, 63.3, 82.2, 89.9, 91.1, 96.6\% after 1, 2, 3, 5, 7, 10 and 14 days from 
treatment. At $250 \mathrm{ppm}$ concentration, mortality values were 22.2, 29.9, 47.7, 52.2, $65.5,83.3,88.86 \%$ after $1,2,3,5,7,10$ and 14 days from treatment. At 200 ppm concentration, mortality values were $19.9,25.5,41.06,44.4,45.5,62.16,81.06 \%$ after $1,2,3,5,7,10$ and 14 days from treatment. At $100 \mathrm{ppm}$ concentration, mortality values were $1.1,2.2,6.6,6.6,9.9,33.3,84.8 \%$ after $1,2,3,5,7,10$ and 14 days from treatment. At $50 \mathrm{ppm}$ concentration, mortality values were zero, 0, 3.3, 4.4, 7.7, 15.5, 41.1\% after 1, 2, 3, 5, 7, 10 and 14 days from treatment. Mortality values at 14 days post-treatment were between $41.1-99.9 \%$ for the different tested concentrations of Neemazal.

The lethal concentrations of Neemazal- T/S 1\% azadirachtin against the adults of Rhizopertha dominica (F.) are shown in table 14. The results showed that the lethal concentrations are exposure period dependent. The higher the exposure period was the lower the values. At 5 day post treatment the $L C_{50}$ value was 173 ppm, the corresponding value at 7 day was significantly decreased to $148 \mathrm{ppm}$, and decreased to $81.2 \mathrm{ppm}$ at 14 day post treatment. The $\mathrm{LC}_{90}$ value was $344 \%$ at 5 day exposure and decreased to $285 \%$ at 7 day exposure and decreased to $185 \mathrm{ppm}$ at 14 day post treatment. The $\mathrm{LC}_{95}$ value was $418 \mathrm{ppm}$ at 5 day exposure and decreased to $343 \mathrm{ppm}$ at 7 day exposure and decreased to $234 \mathrm{ppm}$ at 14 day post treatment.

In this respect El-Lakwah et al., 1993 reported that $R$. dominica adults were least susceptible to Neemazal-F powder than S.oryzea adults.

Table 13. Effect of Neemazal T/S $1 \%$ azadirachtin on adult mortality and reduction in F1 progeny of Rhizopertha dominica (F.) at $30 \pm 1^{\circ} \mathrm{C}$ and $65 \pm 5 \%$ R.H.

\begin{tabular}{|c|c|c|c|c|c|c|c|c|c|}
\hline \multirow{2}{*}{$\begin{array}{l}\text { Conc. } \\
\text { (ppm) }\end{array}$} & \multicolumn{7}{|c|}{$\%$ Adult mortality after indicated period (days) } & \multirow{2}{*}{$\begin{array}{c}\text { Average No. Of } \\
\text { emerged adults after } \\
75 \text { days }\end{array}$} & \multirow{2}{*}{$\begin{array}{c}\text { \% Reduction in } \\
\text { F1-progeny }\end{array}$} \\
\hline & 1 & 2 & 3 & 5 & 7 & 10 & 14 & & \\
\hline 400 & 82.16 & 90 & 98.9 & 99.0 & 99.8 & 99.9 & 99.9 & 189.3 & 75.6 \\
\hline 350 & 47.7 & 67.7 & 83.3 & 94.4 & 97.7 & 99.0 & 99.7 & 245 & 68.42 \\
\hline 300 & 37.7 & 43.2 & 63.3 & 82.2 & 89.9 & 91.1 & 96.6 & 248.6 & 67.96 \\
\hline 250 & 22.2 & 29.9 & 47.7 & 52.2 & 65.5 & 83.3 & 88.86 & 268 & 65.46 \\
\hline 200 & 19.9 & 25.5 & 41.06 & 44.4 & 45.5 & 62.16 & 81.06 & 328.3 & 57.6 \\
\hline 100 & 1.1 & 2.2 & 6.6 & 6.6 & 9.9 & 33.3 & 48.8 & 448.6 & 42.19 \\
\hline 50 & 0 & 0 & 3.3 & 4.4 & 7.7 & 15.5 & 41.1 & 460.6 & 40.64 \\
\hline Control & 0 & 0 & 0 & 0 & 1.1 & 2.2 & 2.2 & 776 & 0 \\
\hline
\end{tabular}


Table 14. Lethal concentrations of Neemazal-T/S 1\% Azadirachtin against the adults of Rhizopertha dominica (F.) at various exposure periods.

\begin{tabular}{|c|c|c|c|c|c|}
\hline \multirow{2}{*}{$\begin{array}{l}\text { Exposure Period } \\
\text { (days) }\end{array}$} & \multicolumn{3}{|c|}{$\begin{array}{c}\text { lethal concentrations (ppm) and their } 95 \% \\
\text { confidence limits }\end{array}$} & \multirow[t]{2}{*}{ Slope \pm SD } & \multirow[t]{2}{*}{$\mathrm{R}$} \\
\hline & $\mathrm{LC}_{50}$ & $\mathrm{LC}_{90}$ & $\mathrm{LC}_{95}$ & & \\
\hline 5 days & $\begin{array}{c}173 \\
(158-189) \\
\end{array}$ & $\begin{array}{c}344 \\
(305-388) \\
\end{array}$ & $\begin{array}{c}418 \\
(362-483) \\
\end{array}$ & $4.3 \pm 1.8$ & 0.9301 \\
\hline 7 days & $\begin{array}{c}148 \\
(136-162)\end{array}$ & $\begin{array}{c}285 \\
(255-317) \\
\end{array}$ & $\begin{array}{c}343 \\
(302-389) \\
\end{array}$ & $4.5 \pm 2.6$ & 0.9131 \\
\hline 14 days & $\begin{array}{c}81.2 \\
(71.4-92)\end{array}$ & $\begin{array}{c}185 \\
(163-210)\end{array}$ & $\begin{array}{c}234 \\
(201-272)\end{array}$ & $3.6 \pm 1.6$ & 0.9149 \\
\hline
\end{tabular}

$\mathrm{R}=$ Correlation Coefficient of regression line.

$\mathrm{SD}=$ Standard deviation of the mortality regression line.

\section{I.9. Effect of organophosphorus pesticide Actellic EC $50 \%$ (pirimiphos methyl) against Rhizopertha dominica (F.) At $30 \pm 1^{\circ} \mathrm{C}$ and $65 \% \pm$ 5\% R.H.}

The results of the effect of Atellic EC $50 \%$ (pirimiphos methyl) on adult mortality and reduction in F1-progeny of Rhizopertha dominica (F.) at $30 \pm 1^{\circ} \mathrm{C}$ and $65 \pm 5 \% \mathrm{RH}$ are tabulated in table 15 . The results indicated clearly that mortality was increased by increasing the pesiticide concentration and the period of exposure. At 10 ppm concentration mortality was $21.06 \%$ at one day after treatment and increased to $96.66 \%$ at 14 days post treatment. At $7.5 \mathrm{ppm}$ mortality was $11.1 \%$ at 1 day exposure and increased to $85.5 \%$ after 14 days post treatment. At 5 ppm mortality was $7.7 \%$ at 1 day exposure and increased to $50 \%$ at 14 days post treatment. At 2.5 ppm mortality was $1.1 \%$ at 1 day exposure and increased to $36.6 \%$ at 14 days post treatment. At $1.25 \mathrm{ppm}$ mortality was $1.1 \%$ at 1 day and increased to $19.8 \%$ after 14 days post treatment. The results showed that adult mortalities of Rhizopertha dominica were between $19.8-96.66 \%$ at the various concentration of pirimiphos methyl after 14 days post-treatment.

The lethal concentrations of Actellic EC 50\% against the adults of Rhizopertha dominica (F.) are tabulated in table 16 . The results showed that the lethal concentrations are exposure period dependent. The higher the exposure period was the lower the values. At 5 days post treatment the $\mathrm{LC}_{50}$ value was $5.8 \mathrm{ppm}$, the corresponding value at 7 days was significantly decreased and amounted $4.9 \mathrm{ppm}$ and decreased to $3.1 \mathrm{ppm}$ at 14 days post treatment. The $\mathrm{LC}_{90}$ value was $20.6 \mathrm{ppm}$ at 5 
days exposure and decreased to $20.1 \mathrm{ppm}$ at 7 days and decreased to $8.9 \%$ at 14 days post treatment. The $\mathrm{LC}_{95}$ value was $29.6 \mathrm{ppm}$ at 5 days post treatment and declined to $12.1 \mathrm{ppm}$ after 14 days from treatment.

Table 15. Effect of Actellic EC 50\% (Pirimiphos methyl) on adult mortality and reduction in F1-progeny of Rhizopertha dominica (F.) at $30 \pm 1^{\circ} \mathrm{C}$ and $65 \pm 5 \%$ R.H.

\begin{tabular}{|c|c|c|c|c|c|c|c|c|c|}
\hline \multirow{2}{*}{ Conc . (ppm) } & \multicolumn{7}{|c|}{$\%$ Adult mortality after indicated period (days) } & \multirow{2}{*}{$\begin{array}{l}\text { Average No. of } \\
\text { emerged adults } \\
\text { after } 75 \text { days }\end{array}$} & \multirow{2}{*}{$\begin{array}{c}\% \text { Reduction in } \\
\text { F1-progeny }\end{array}$} \\
\hline & 1 & 2 & 3 & 5 & 7 & 10 & 14 & & \\
\hline 10 & 21.06 & 46.6 & 69.9 & 77.7 & 79.88 & 81.11 & 96.66 & 3.6 & 95.6 \\
\hline 7.5 & 11.1 & 35.5 & 46.6 & 68.8 & 70.3 & 74.4 & 85.5 & 13.6 & 78.6 \\
\hline 5 & 7.7 & 17.7 & 24.4 & 31.11 & 33.3 & 36.6 & 50 & 52.6 & 44.6 \\
\hline 2.5 & 1.1 & 3.3 & 6.6 & 8.8 & 23.3 & 31.06 & 36.6 & 67 & 18.4 \\
\hline 1.25 & 1.1 & 5.5 & 7.7 & 13.32 & 15.5 & 18.8 & 19.8 & 73.6 & 5.7 \\
\hline Control & 0 & 0 & 0 & 0 & 2.2 & 3.3 & 3.3 & 65.3 & 0 \\
\hline
\end{tabular}

Table 16. Lethal concentrations of Actellic EC 50\% (Pirimiphos methyl) against the adults of Rhizopertha dominica (F.) at various exposure periods.

\begin{tabular}{|c|c|c|c|c|c|}
\hline \multirow{2}{*}{$\begin{array}{c}\text { Exposure Period } \\
\text { (days) }\end{array}$} & \multicolumn{3}{|c|}{$\begin{array}{c}\text { lethal concentrations ( } \mathrm{ppm} \text { ) and their } 95 \% \\
\text { confidence limits }\end{array}$} & \multirow[t]{2}{*}{ Slope \pm SD } & \multirow[t]{2}{*}{$\mathrm{R}$} \\
\hline & $\mathrm{LC}_{50}$ & $\mathrm{LC}_{90}$ & $\mathrm{LC}_{95}$ & & \\
\hline 5 days & $\begin{array}{c}5.8 \\
(4.7-7.1)\end{array}$ & $\begin{array}{c}20.6 \\
(13-33)\end{array}$ & $\begin{array}{c}29.6 \\
(16.8-52)\end{array}$ & $2.3 \pm 0.66$ & 0.9021 \\
\hline 7 days & $\begin{array}{c}4.9 \\
(4-6.2) \\
\end{array}$ & $\begin{array}{c}20.1 \\
(12.2-35.0)\end{array}$ & $\begin{array}{c}30.1 \\
(16.3-59)\end{array}$ & $2.05 \pm 0.32$ & 0.9358 \\
\hline 14 days & $\begin{array}{c}3.1 \\
(3-4)\end{array}$ & $\begin{array}{c}8.9 \\
(7-12)\end{array}$ & $\begin{array}{c}12.1 \\
(8.5-17.3)\end{array}$ & $2.8 \pm 0.57$ & 0.9371 \\
\hline
\end{tabular}

$\mathrm{R}=$ Correlation Coefficient of regression line.

$\mathrm{SD}=$ Standard deviation of the mortality regression line. 


\section{I.10. Effect of the organophosphorous pesticide malathien EC $57 \%$ (malathion) against Rhizopertha dominica (F.) at $30 \pm 1^{\circ} \mathrm{C}$ and $65 \pm 5 \%$ R.H.}

The results of the effect of malathion EC $57 \%$ on adult mortality and reduction in F1- progeny of Rhizopertha dominica (F.) at $30 \pm 1^{\circ} \mathrm{C}$ and $65 \pm 5 \%$ R.H. are presented in table 17 . The results indicated clearly that mortality was increased by increasing the pesticide concentration and the period of exposure. At $30 \mathrm{ppm}$ concentration, mortality was $7.7 \%$ at 1 day after treatment and increased to $81.1 \%$ at 14 days post treatment. At $20 \mathrm{ppm}$ concentration, mortality was $6.6 \%$ at 1 day exposure and increased to $70.9 \%$ at 14 days exposure period. At $15 \mathrm{ppm}$ concentration, mortality was $6.6 \%$ at 1 day exposure and increased to $60.2 \%$ at 14 days post treatment. At $10 \mathrm{ppm}$ concentration, mortality was $4.4 \%$ at 1 day exposure and increased to $50.2 \%$ at 14 days exposure period. At $7.5 \mathrm{ppm}$ concentration, mortality was $4.4 \%$ at 1 day exposure and increased to $45.7 \%$ at 14 days post treatment. At $5 \mathrm{ppm}$ concentration, mortality was $2.2 \%$ at 1day exposure and increased to $42.3 \%$ after 14 days post treatment. At $2.5 \mathrm{ppm}$ concentration, mortality was $1.1 \%$ at 1 day exposure and increased to $36.6 \%$ at 14 days post treatment.

The lethal concentrations of malathion EC $57 \%$ against the adults of Rhizopertha dominica (F.) are tabulated in table 18. The results showed that the lethal concentrations are exposure period, dependent. The higher the exposure period was the lower the values. At 14 day post treatment $\mathrm{LC}_{50}$ value was $7.2, \mathrm{LC}_{90}$ value was 98.6, $L_{95}$ value was $207 \mathrm{ppm}$. The results of the lethal concentrations indicated clearly that Rhizopertha dominica adults were resistant to malathion. On the other hand, pirimiphos methyl (Actellic) was more effective against this insect species than malathion.

Results of the toxicity index given in table (19) revealed that Actellic was the most effective insecticide against Rhizopertha dominica adults followed by malathion and Neemazal was the least effective one.

In this respect El-Lakwah et al. (2000) reported that Rhizopertha dominica was the most tolerant species to pirimiphos-methyl in comparison to Sitophilus oryzae and Tribolium castaneum. Also Rhizopertha dominica was high resistant to malathion.

Meanwhile, the efficacy of the botanical insecticide Neemazal-W powder contains $10 \%$ Azadirachtin was studied alone by El-Lakwah, (1997) and in mixtures with the $\mathrm{LC}_{50}$ of malathion and sumithion on mortality and reduction in $\mathrm{F}_{1}$ - progeny of Rhizopertha dominica. The results showed that insect mortality was increased with increasing exposure period and concentration of the compounds. Toxicity data revealed that $R$. dominica - adults were high resistant to malathion and less resistant 
to sumithion. Co-toxicity resulted from addition of the $\mathrm{LC}_{50}$ of malathion (14.5 ppm) to Neemazal at various concentrations for $R$. dominica showed an additive effect at all tested concentrations. In case of the mixture of sumithion plus Neemazal, an additive effect was obtained at higher concentrations (500,1000 ppm), but at 50, 100 and 250 ppm an antagonistic effect was achieved. Thus, it could be recommended to apply Neemazal as grain protectant against stored product insects in frame of an integrated pest management system and to stop the use of malathion if the grain was infested with $R$. dominica due to its high resistant to this insecticide.

Also El-Kashlan, 1999 reported that $R$. dominica was highly tolerant to malathion.

Table 17. Effect of malathion EC $57 \%$ on adult mortality and reduction in F1

\begin{tabular}{|c|c|c|c|c|c|c|c|c|c|}
\hline \multirow{2}{*}{$\begin{array}{l}\text { Conc. } \\
\text { (ppm) }\end{array}$} & \multicolumn{7}{|c|}{$\%$ Adult mortality after indicated period (days) } & \multirow{2}{*}{$\begin{array}{l}\text { Average No. of } \\
\text { emerged adults } \\
\text { after } 75 \text { days }\end{array}$} & \multirow{2}{*}{$\begin{array}{c}\text { \% Reduction in } \\
\text { F1-progeny }\end{array}$} \\
\hline & 1 & 2 & 3 & 5 & 7 & 10 & 14 & & \\
\hline 30 & 7.7 & 9.9 & 16.6 & 27.7 & 36.6 & 56.6 & 81.1 & 225 & 44.6 \\
\hline 20 & 6.6 & 8.8 & 14.4 & 26.6 & 33.3 & 51.06 & 70.9 & 263.3 & 35.15 \\
\hline 15 & 6.6 & 8.8 & 12.2 & 16.6 & 25.5 & 49.96 & 60.2 & 324 & 20.19 \\
\hline 10 & 4.4 & 7.7 & 11.1 & 15.5 & 24.4 & 47.73 & 50.2 & 365 & 10.09 \\
\hline 7.5 & 4.4 & 5.5 & 8.8 & 12.2 & 21.1 & 42.2 & 45.7 & 378.3 & 6.82 \\
\hline 5 & 2.2 & 3.3 & 5.5 & 9.9 & 14.4 & 39.96 & 42.3 & 383.3 & 5.59 \\
\hline 2.5 & 1.1 & 2.2 & 3.3 & 7.7 & 13.3 & 35.53 & 36.6 & 394.4 & 2.85 \\
\hline Control & 0 & 0 & 0 & 0 & 0 & 2.2 & 3.3 & 406 & 0 \\
\hline
\end{tabular}

Table 18. Lethal concentrations of malathion EC $57 \%$ against the adults of Rhizopertha dominica (F.) at 14 day.

\begin{tabular}{|c|c|c|c|c|c|}
\hline \multirow{2}{*}{ Exposure Period (Days) } & \multicolumn{3}{|c|}{ lethal concentrations (\%w/w) and their 95\% } & & \multirow{2}{*}{ Slope \pm SD } \\
\cline { 2 - 4 } & $\mathrm{LC}_{50}$ & $\mathrm{LC}_{90}$ & $\mathrm{LC}_{95}$ & $\mathrm{R}$ \\
\cline { 2 - 6 } & 7.2 & $\begin{array}{c}98.6 \\
(42.9-227)\end{array}$ & $\begin{array}{c}207 \\
(71-606)\end{array}$ & \multirow{2}{*}{$1.12 \pm 0.11$} & 0.9475 \\
\hline
\end{tabular}

$\mathrm{SD}=$ Standard deviation of the mortality regression line.

$\mathrm{R}=$ Correlation coefficient of regression line. 
Table 19. Toxicity index of the tested pesticide against the adults of Rhizopertha dominica (F.) after 14 days from treatment.

\begin{tabular}{|c|c|c|c|c|c|c|}
\hline \multirow[t]{2}{*}{ Pesticide } & \multicolumn{2}{|c|}{$\begin{array}{l}\text { Lethal concentration after } \\
14 \text { days }\end{array}$} & \multicolumn{2}{|c|}{ Toxicity index } & \multirow[t]{2}{*}{ Slope \pm SD } & \multirow[t]{2}{*}{ R. } \\
\hline & $\mathrm{LC}_{50} \mathrm{ppm}$ & $\mathrm{LC}_{95} \mathrm{ppm}$ & $\mathrm{LC}_{50}$ & $\mathrm{LC}_{95}$ & & \\
\hline Actellic & 3.1 & 12.1 & 100 & 100 & $2.8 \pm 0.57$ & 0.9371 \\
\hline Malathion & 7.2 & 2.07 & 43.05 & 5.84 & $1.12 \pm 0.11$ & 0.9475 \\
\hline Neemazal & 81.2 & 234 & 3.8 & 5.2 & $3.6 \pm 1.6$ & 0.9149 \\
\hline
\end{tabular}

\section{REFERENCES}

1. Abbott, W. S. 1925. A method of computing the effectiveness of an insecticide. J. Econ. Ent. 18: 265-269.

2. El-Kashlan, I. H. 1999. Toxicity of malathion versus other control agents against certain stored product insects. Annals of Agric. SC., Moshtohor, vol. 37 (1): 629 637.

3. El-lakwah, F. A. M., Omnia M. Khaled and A. A. Darwish. 1992. Toxic effects of pulverized Black pepper ( Piper nigrum.L) on some stored product insects. Annals of Agric. Sc., Moshtohor, vol. 30(4).

4. El-Lakwah, F. A., A. E. Abd El-Aziz and I. H. El-Kashlan. 2000. Joint action and effectiveness of black pepper seeds extract with modified atmospheres against some stored product insects. Annals of Agric. Sc., Moshtohor,vol.38(4):25292542.

5. El-Lakwah, F. A. M. 1997. Toxicity of the botanical insecticide neemazal-w(powder contains $10 \%$ azadirachtin) alone, and in mixtures with two insecticides against the lesser grain borer Rhizopertha dominica (F.). Annals of Agric. Sc. Moshtohor, Vol. 35(4):2583-2594.

6. El-lakwah, F. A. M., R. A. Mohamed and I. H. El-kashlan. 2001. Effectiveness of some grain protectants alone /or under controlled atmosphere of carbon dioxide against the lesser grain borer, Rhizopertha aominica (F.)(Coleoptera: Bostrychidae). Annals of Agric. Sc., Moshtohor, vol. 39(3). : 1741 - 1754. 
7. El-lakwah, F. A. M., A. A. Darwish, M. M. Khattab and A. E. Abd -El Aziz. 1993. Acute and chronic toxicities of neemazal-F against some stored product insects. Annals of Agric. C., Moshtohor, vol. 31(1).

8. Finney, D. J. 1971. Probit analysis $3^{\text {rd }}$ ed. Cambridge Univ. Press, Cambridge, England., pp 333.

9. Ketkar, C. M. 1987. Use of tree-dervied non-edible oils as surface protectants chinensis.

10. Mohonds, J. 1969. Aust. J. Chem. 22, 1803. (Cited from Jeffery et. al. 1996.

11. Nikpay, A.: 2006. Assessing the effectiveness of five diatomaceous earth formulations on steel surfaces as structural treatments, against two species of Coleoptera in festing stored grain: International Pest Control. 2006. 48: (6), 310 313. 28 ref.

12. Okudak, T. J. 1983. Chem. Soc., Perkin Trans., 1965. (Cited from Jeffery et al., 1996.

13. Saxena, R. C., H. D. Justo and Jr., P. B. Epino. 1984. Evaluation and utilization of neem cake against the brown planthopper, Nilaparvata lugens (Homoptera: Delphacidae). J. Econ. Entomol. 77: 502-507.

14. Yaday, T. D. 1985. Antiovipositional and ovicidal toxicity of neem (Azadirachta indica A. Juss) oil against three species of callosobruchus. Neem News. 2:5-6. 
فاعلية بعض المساحيق النباتية والمبيدات ضد حشرة ثاقبة الحبوب الصغرى

فارس أمين اللقوة 1 ، أحمد عبد الغفار عبده درويش 1 ، رفعت عبد الثافى محمد 2 ، منار يوسف أمين 2

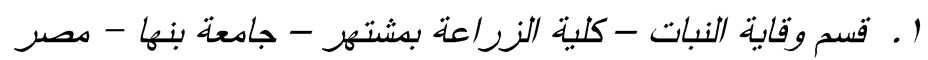

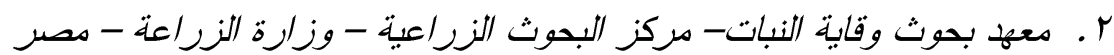

تهدف هذه الدراسة إلى تقييم فاعلية بعض المساحيق النباتية وهى :- مسحوق بذور الفلفل

الأسود ومسحوق بر اعم أزهار القرنفل ومسحوق ثمار الثطة ومسحوق القرفة ومسحوق التربة الدياتو مية مقارنة بمسحوف قاتلسوس.

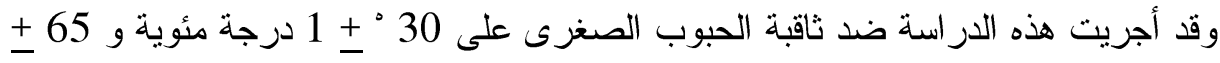

5 رطوبة نسبية ـ وكذلك تقييم فاعلية أثنين من المركبات الفوسفورية العضويةوهما الملاثيون

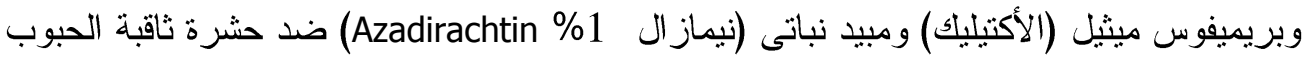

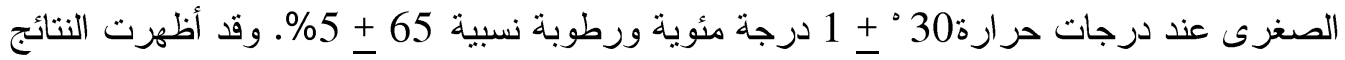

يزداد معدل موت الحشر ات الكاملة بزيادة فترة التعريض و التركيز

ولقد أوضحت نتائج المساحيق المختلفة المستخدمة ضد الأطوار الكاملة لحشرة ثاقبة

الحبوب الصغرى أن مسحوق التربة الدياتومية هو الأكثر فاعلية يليه مسحوق بذور الفلفل الاسود ثم

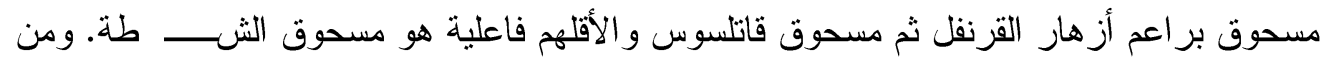

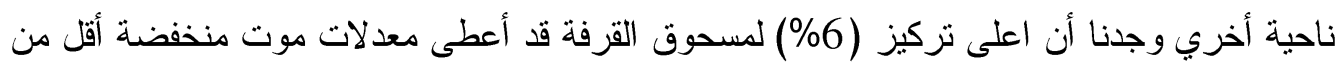

$$
\text { 40 وذذلك بعد أسبو عين من المعاملة . }
$$

وقد أوضحت نتائج دليل السمية للمبيدات الحشرية المختلفة ضد الاطو ار الكاملة لحشرة

ثاقبة الحبوب الصغرى أن مبيد الأكتيليك هو الأعلى فاعلية يليه الملاثيون وأقلهم فاعلية هو مبيد

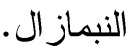

